\title{
Prevalence of selected zoonotic diseases and risk factors at a human-wildlife-livestock interface in Mpumalanga Province, South Africa
}

\author{
Gregory J.G. Simpson ${ }^{\mathrm{a}}$, Vanessa Quan ${ }^{\mathrm{b}}$, John Freanc, Darryn L. Knobeld, Jennifer Rossouwc, \\ Jacqueline Weyerc, Tanguy Marcottye, Jacques Godfroidf, Lucille H. Blumbergc
}
a Production Animal Studies, Faculty of Veterinary Science, University of Pretoria, South Africa. gjgsimpson@gmail.com

b Division of Public Health Surveillance and Response, National Institute for Communicable Diseases, Sandringham, a division of the National Health Laboratory Service, South Africa. vanessaq@nicd.ac.za

${ }^{\mathrm{c}}$ Centre for Emerging Zoonotic and Parasitic Diseases, National Institute for Communicable Diseases, Sandringham, a division of the National Health Laboratory Service, South Africa.johnf@nicd.ac.za, jennyr@nicd.ac.za, jacquelinew@nicd.ac.za, lucilleb@nicd.ac.za

${ }^{\mathrm{d}}$ Center for Conservation Medicine and Ecosystem Health, Ross University School of Veterinary Medicine, St. Kitts and Nevis.dknobel@rossvet.edu.kn

e Faculty of Science, University of Namur, Namur, Belgium. Department of Veterinary Tropical Diseases, Faculty of Veterinary Science, University of Pretoria, South Africa. tanguy.marcotty@unamur.be

${ }^{\mathrm{f}}$ Faculty of Biosciences, Fisheries and Economics, Department of Artic and Marine Biology, University of Troms $\emptyset$, Norway. Department of Veterinary Tropical Diseases, Faculty of Veterinary Science, University of Pretoria, South Africa. jacques.godfroid@uit.no

*Authors sharing first authorship 
Corresponding author:

Gregory Simpson

Email: gjgsimpson@gmail.com;

Telephone: +27(0)125298361

Running title: Zoonoses at a human-wildlife-livestock interface (46 characters)

\begin{abstract}
A lack of surveillance and diagnostics for zoonotic diseases in rural human clinics limits clinical awareness of these diseases. We assessed the prevalence of nine zoonotic pathogens in a pastoral, low-income, HIV-endemic community bordering wildlife reserves in South Africa. Two groups of participants were included: malaria-negative acute febrile illness (AFI) patients, called febrilers, at three clinics (n=74) and secondly farmers, herders and veterinary staff found at five government cattle dip-tanks, called dip-tanksters $(n=64)$. Blood samples were tested using one PCR (Bartonella spp.) and eight antibody-ELISAs, and questionnaires were conducted to assess risk factors.
\end{abstract}

Seventy-seven percent of febrilers and $98 \%$ of dip-tanksters had at least one positive test. Bartonella spp. (PCR 9.5\%), spotted fever group Rickettsia spp. (IgM 24.1\%), Coxiella burnetii. (IgM 2.3\%) and Leptospira spp. (IgM 6.8\%) were present in febrilers and could have been the cause of their fever. Dip-tanksters and febrilers had evidence of past infection to Rickettsia spp. (IgG 92.2\% and 63.4\%, respectively) and C. burnetii (IgG 60.9\% and 37.8\%, respectively). No 
Brucella infection nor current Bartonella infection was found in the dip-tanksters, although they had higher levels of recent exposure to Leptospira spp. (IgM 21.9\%) compared to the febrilers. Low levels of West Nile and Sindbis, and no Rift Valley fever virus exposure were found in either groups. The only risk factor found to be significant was attending dip-tanks in febrilers for $Q$ fever $(\mathrm{p}=0.007)$.

Amoxicillin is the local standard treatment acute febrile illness, but would not be effective for Bartonella spp. infections, spotted fever group rickettsiosis, $\mathrm{Q}$ fever infections, nor the viral infections. There is a need to revise acute febrile illness treatment algorithms, educate medical and veterinary staff about these pathogens, especially spotted fever group rickettsiosis and $Q$ fever, support disease surveillance systems and inform the population about reducing tick and surface water contact.

Keywords: Zoonosis; South Africa, surveillance, one health, human-wildlife-livestock interface

\section{Introduction}

Zoonotic diseases are caused by pathogens naturally transmitted directly or indirectly (e.g. by vectors) between animals (usually vertebrates) and humans. Of all currently known human pathogens, $61 \%$ are considered to be zoonotic, whilst $73 \%$ of all emerging and re-emerging infections are also zoonotic (Jones et al. 2008). An estimated 2.5 billion human cases related to zoonotic infections occur globally each year, causing 2.7 million deaths (Grace et al. 2012a). Zoonoses are estimated to account for one quarter of the disease burden in low-income 
Table I. Selected studies of zoonotic aetiologies of acute febrile illness in sub-Saharan Africa.

\begin{tabular}{|c|c|c|c|}
\hline Disease & Population & Result & Reference \\
\hline Brucellosis & $\begin{array}{l}\text { Febrile hospital patients with a } \\
\text { history of animal contact, } \\
\text { north-eastern Kenya (n=1067) }\end{array}$ & $\begin{array}{l}\text { 13.7\% qPCR-positive for } \\
\text { Brucella abortus, 11\% ELISA } \\
\text { seropositive for Brucella spp. } \\
\text { IgM/IgG }\end{array}$ & (Njeru et al. 2016) \\
\hline Leptospirosis & $\begin{array}{l}\text { Febrile hospital inpatients } \\
\text { (n=870), northern Tanzania }\end{array}$ & $\begin{array}{l}9 \% \text { serologically confirmed } \\
\text { acute leptospirosis by MAT* } \\
\text { (representing } 20 \text { antigen } \\
\text { serovars) }\end{array}$ & $\begin{array}{l}\text { (Biggs et al. 2011; Prabhu et al. } \\
\text { 2011) }\end{array}$ \\
\hline $\begin{array}{l}\text { Spotted fever group } \\
\text { rickettsiosis }\end{array}$ & & $\begin{array}{l}\text { 8\% serologically confirmed by } \\
\geq 4 \text {-fold increase in IgG to } \\
\text { Rickettsia conori by IFA** }\end{array}$ & \\
\hline Q fever & & $\begin{array}{l}5 \% \text { serologically confirmed } \\
\text { acute Q fever by } \geq 4 \text {-fold } \\
\text { increase in IgG to Coxiella } \\
\text { burnetii by IFA** }\end{array}$ & \\
\hline $\begin{array}{l}\text { Spotted fever group } \\
\text { rickettsiosis }\end{array}$ & $\begin{array}{l}\text { Population based infectious } \\
\text { disease study }(n=357) \text { and } \\
\text { febrile clinic patients ( } n=699) \text {, } \\
\text { western Kenya }\end{array}$ & $\begin{array}{l}57 \% \text { had detectable IgG against } \\
\text { SFG antigen and 7\% were PCR- } \\
\text { positive (gltA assay) for } \\
\text { Rickettsia spp. (R. felis DNA was } \\
\text { identified) }\end{array}$ & (Maina et al. 2012) \\
\hline Bartonellosis & $\begin{array}{l}\text { Febrile patients, Democratic } \\
\text { Republic of the Congo }(n=155)\end{array}$ & $\begin{array}{l}4.5 \% \text { serologically positive for } \\
\text { Bartonella henselae, } B \text {. } \\
\text { quintana, or B. clarridgeiae spp. } \\
\text { by IFA**. }\end{array}$ & (Laudisoit et al. 2011) \\
\hline
\end{tabular}

* Microscopic agglutination test; ${ }^{* *}$ immunofluorescent assay 
countries (Grace et al. 2012b). Poverty raises the risk of zoonotic disease in communities living in close contact with their livestock or with wildlife (Grace et al. 2017).

Studies in sub-Saharan Africa investigating acute febrile illness (AFI) patients have found evidence of present or past zoonotic infections (Table I). In populations with a high prevalence of HIV infection, this proportion of zoonotic infections may be even higher due to immunosuppression, HIV also increases the clinical severity of many zoonoses and results in a more protracted, chronic illness (Froberg et al. 2004; Biggs et al. 2011).

A lack of human surveillance for zoonotic diseases (Rodríguez-Prieto et al. 2015) and laboratory capacity causes a lack of clinical awareness, leading to under-diagnosis and consequently mismanagement of cases (John et al. 2008). In this light, the early detection of new and reemerging human pathogens is also problematic (Zumla et al. 2016). Gaps in data on the burden of zoonotic infections are especially pressing in the study site, a pastoral setting where humans, their domestic animals and wildlife have frequent direct and indirect contact. The zoonoses selected for this study were based on prior information concerning infection prevalence and laboratory capacity. The study aimed to document the prevalence of nine zoonoses in this setting; investigate the proportion of acute febrile illness patients and high-risk cattle farmers, herders and veterinary staff that have evidence of exposure or infection to these zoonoses; and identify risk factors for these zoonoses. Implications for public health surveillance, diagnostic and treatment protocols used in this setting are explored. 


\section{Materials and methods}

\section{Study site}

The study was implemented in three rural government primary health care clinics and five government cattle dip-tanks in Bushbuckridge Municipality, Mpumalanga Province, South Africa (Figure 1). The prevalence of HIV infection in the province is $14.5 \%$ and the municipality is situated in the Ehlanzeni District, where levels of HIV are amongst the highest of all districts in the country (between 16\% and 22\%) (Shisana et al. 2014).

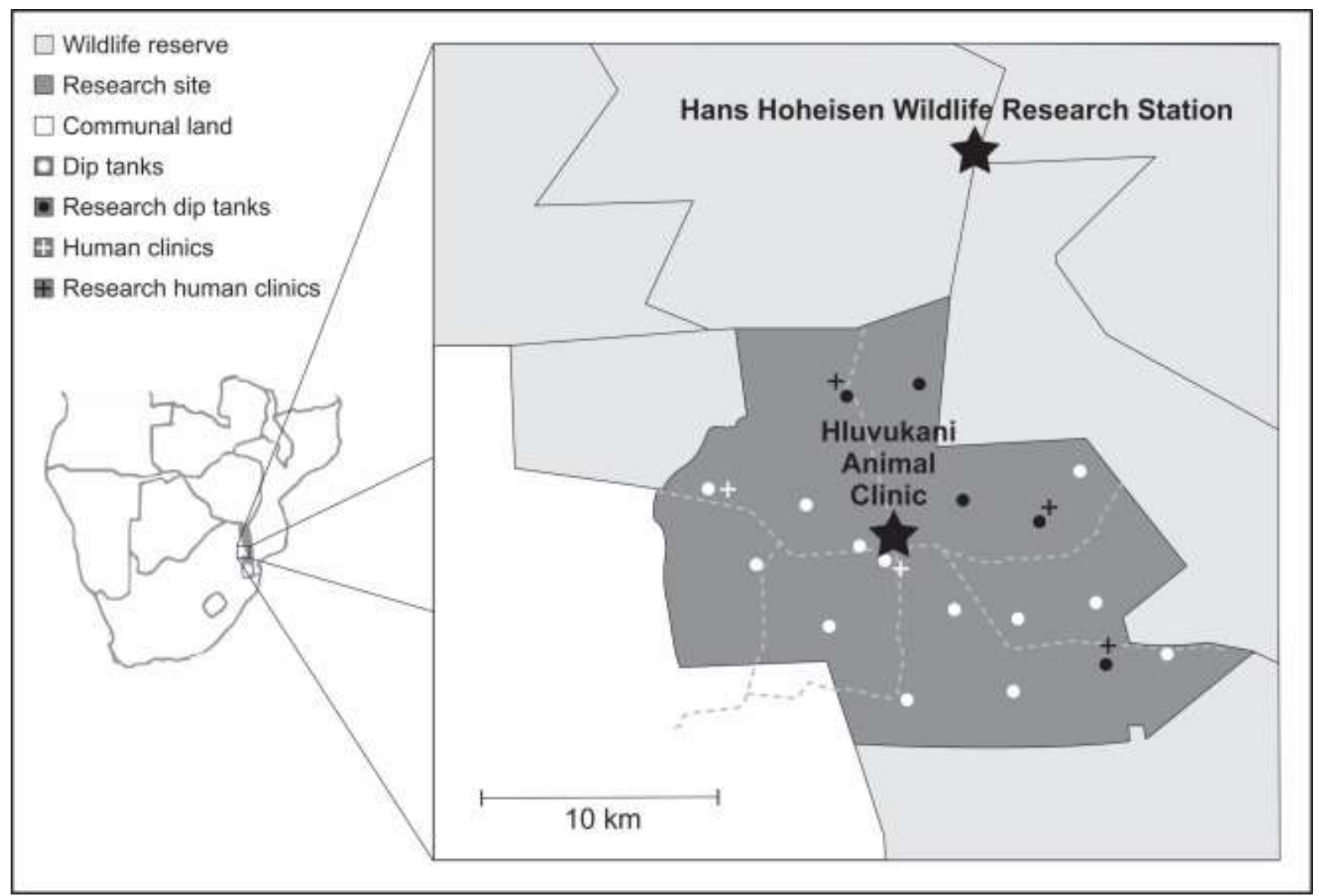

Figure 1. Location of the research site, Bushbuckridge Municipality, Mpumalanga Province, South Africa. 
The study area was in the Mnisi Community Programme area, containing the Hans Hoheisen Wildlife Research Station and Hluvukani Animal Clinic, and is a joint initiative by the University of Pretoria with the Mpumalanga Veterinary Services and the Mnisi Traditional Authority, to promote sustainable livelihoods through research into human and animal health, animal production and natural resource utilisation. Approximately 40,000 people live in 8,500 households (Statistics South Africa (SSA) 2012), with 72\% of all households owning at least one species of animal and agro-pastoralist farming being the primary subsistence activity (Berrian et al. 2016). Chickens are owned in 55\% of households, cattle in 25\%, goats in $16 \%$, pigs in $5 \%$ and companion animals in 36\% (Berrian et al. 2016). The community shares three-quarters of its boundary with wildlife reserves. In the communal area there are hares, small antelope,

rodents, small carnivores and in the wildlife reserves, all wildlife typical of "big five" reserves in this region. In these wildlife areas brucellosis has been detected in buffalo, other antelope, zebra, lions, hyenas and other animals, including monkeys (De Vos and Van Niekerk 1969; Gorsich et al. 2015). Malaria is endemic in the area, but the average annual incidence of the infection has decreased over the past 10 years, due to intensive control activities (Maharaj et al. 2013). The contribution of malaria to the syndrome of AFI has thus reduced.

\section{Participant recruitment}

The sample size calculation was done using an infinite population, where 59 samples are required to detect a disease with $95 \%$ chance when the actual prevalence of the disease is $5 \%$ (Thrusfield 1995). In addition, 64 samples give unilateral 95\% confidence intervals of proportions of $12 \%$ maximum, which was deemed sufficient for the study. 
The study involved two groups of participants. The first comprised patients diagnosed with AFI at the clinics, hereafter called febrilers. An AFI case was defined as a patient with documented axillary temperature $\geq 37.5^{\circ} \mathrm{C}$, or a history of fever within the previous 72 hours, whom the clinic staff would routinely test for malaria, in terms of the clinic standard operating procedure.

Patients who tested negative for malaria were referred to the study nurse to be enrolled in this study. All patients $\geq 18$ years of age who met this case definition were eligible for enrollment from October 2012 to June 2013. Information was captured onto a standard case information form (CIF). This CIF inquired about a variety of symptoms and questions related to risk factors for zoonotic disease, and diagnosis, treatment and outcome. The selected risk factors were a variety of contacts (such as handling and consumption) with various domestic animals, presence at dip-tanks and tick bites. Blood samples (one coagulated for serum and one EDTA anticoagulated) for laboratory tests were drawn at the time of presentation (acute sample) and the patients were asked to return two to three weeks later to provide follow-up convalescent samples. A study nurse facilitated enrolment of volunteers at all the clinic sites.

The second group comprised cattle farmers, herders and government veterinary staff (animal health technicians and veterinarians), who attended any of five cattle dip-tanks for weekly stock inspections and tick control in the area in one week in June 2013 (Figure 2). This group were called dip-tanksters. They were recruited for interviewing and provided blood samples as described above for the febrilers, but without follow-up samples. A CIF with the risk factors detailed above was also completed, but excluded the clinical symptoms, diagnosis or treatment and outcome information. All information was captured onto a Microsoft Excel database. 


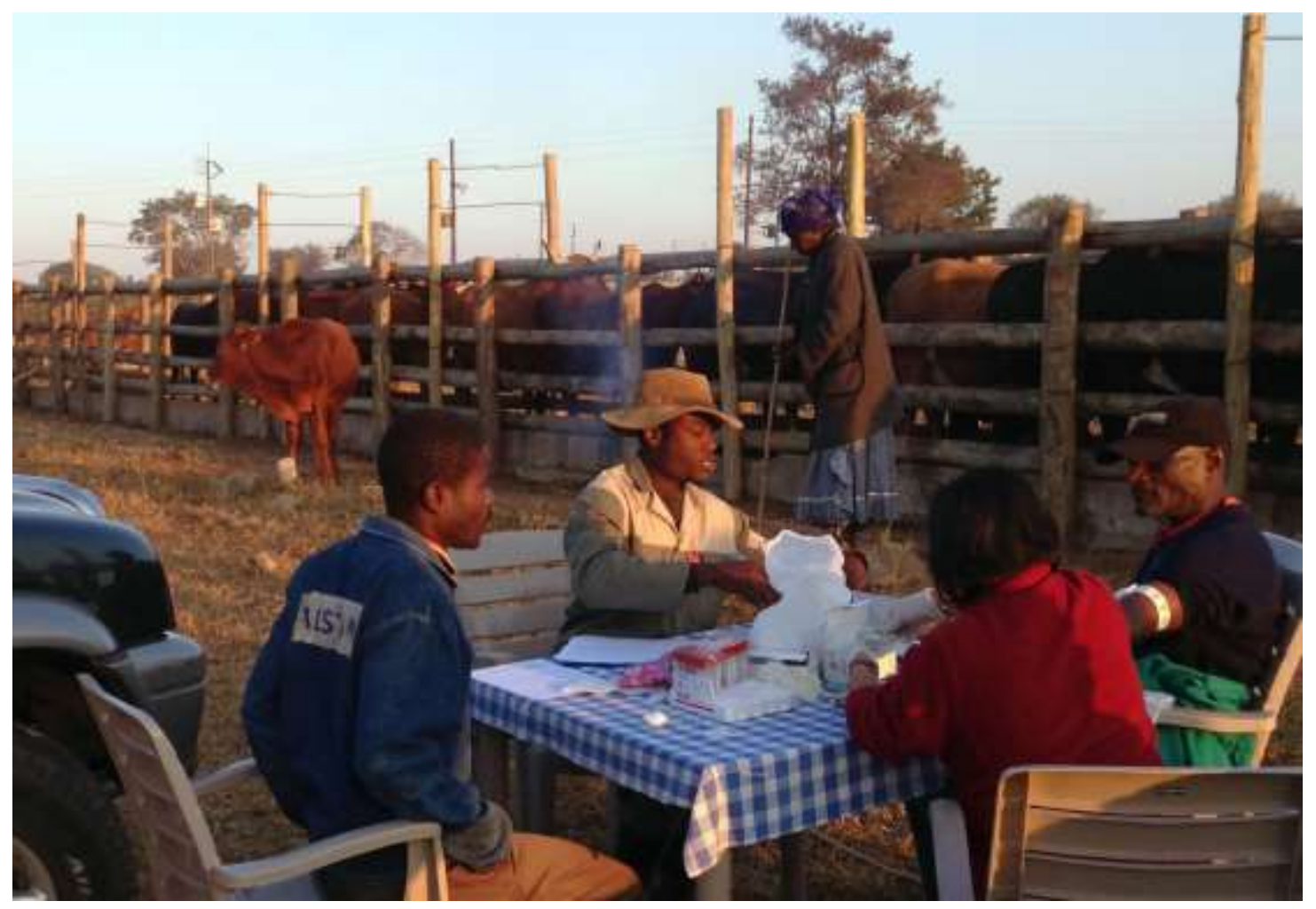

Figure 2. Sampling of dip-tanksters at a dip-tank.

\section{Laboratory methods}

Laboratory testing for all samples was performed at the National Institute for Communicable Diseases. Tests for a panel of nine known endemic bacterial and viral zoonoses in South Africa were used in this study (Table 2). 
Table 2. Panel of tests performed on blood samples from acute febrile patients and healthy subjects. Sensitivity and specificity are included if available.

\begin{tabular}{|c|c|c|c|c|}
\hline Disease agent/s & Diagnostic assay & Samples tested & Interpretation of results & Reference \\
\hline Bartonellosis & $\begin{array}{l}\text { PCR*: Bartonella spp. } \\
\text { 16S/23S reran } \\
\text { internal transcribed } \\
\text { spacer (ITS) region } \\
\text { (in-house) and } \\
\text { sequencing. }\end{array}$ & $\begin{array}{l}\text { Acute whole blood } \\
\text { samples from all } \\
\text { participants. All } \\
\text { positive amplicons } \\
\text { were sequenced }\end{array}$ & $\begin{array}{l}\text { Fragment sizes variable } \\
\text { depending on species } \\
\text { approximately } 640-788 \\
\text { bp for outer primers and } \\
481-573 \text { bp for inner } \\
\text { primers }\end{array}$ & $\begin{array}{l}\text { (Trataris et al. } \\
\text { 2012) }\end{array}$ \\
\hline Brucellosis & $\begin{array}{l}\text { Serology (total } \\
\text { antibodies): } \\
\text { Brucellacapt }{ }^{\circledR} \text { assay } \\
\text { (Vircell S.L., Spain) }\end{array}$ & $\begin{array}{l}\text { Acute serum } \\
\text { samples from all } \\
\text { participants }\end{array}$ & $\begin{array}{l}\text { Titres higher than 1:320 } \\
\text { were deemed positive }\end{array}$ & $\begin{array}{l}96 \% \text { sens. \& } \\
97.5 \% \text { spec } \\
\text { (Casao et al. } \\
2004 \text { ) }\end{array}$ \\
\hline $\begin{array}{l}\text { Chikungunya, Rift } \\
\text { Valley fever, } \\
\text { Sindbis fever and } \\
\text { West Nile fever } \\
\text { viruses }\end{array}$ & HAI:** in-house assay & $\begin{array}{l}\text { Serum samples } \\
\text { from all } \\
\text { participants }\end{array}$ & $\begin{array}{l}\text { Titres higher than 1:20 } \\
\text { were deemed positive }\end{array}$ & $\begin{array}{l}\text { (Lennette and } \\
\text { Schmidt 1979) }\end{array}$ \\
\hline $\begin{array}{l}\text { Chikungunya, Rift } \\
\text { Valley fever, } \\
\text { Sindbis fever and } \\
\text { West Nile fever } \\
\text { viruses }\end{array}$ & $\begin{array}{l}\text { IgM capture ELISA***: } \\
\text { in-house assay }\end{array}$ & $\begin{array}{l}\text { Serum samples that } \\
\text { tested positive per } \\
\text { arbovirus HAI }\end{array}$ & $\begin{array}{l}\text { Percentage positivity } \\
\text { values higher than the } \\
\text { calculated run-based or } \\
\text { population based cut-off } \\
\text { values }\end{array}$ & $\begin{array}{l}\text { RVF: } 96.5 \% \\
\text { sens. \& 99.4\% } \\
\text { spec. } \\
\text { (Paweska et al. } \\
2005 \text { ) }\end{array}$ \\
\hline Leptospirosis & $\begin{array}{l}\text { IgM ELISA: Panbio }{ }^{\circledR} \\
\text { Leptospira (Standard } \\
\text { Diagnostics Inc., } \\
\text { Republic of Korea). }\end{array}$ & $\begin{array}{l}\text { Convalescent } \\
\text { serum samples or } \\
\text { acute samples } \\
\text { where convalescent } \\
\text { samples not } \\
\text { available }\end{array}$ & $\begin{array}{l}\text { Index values calculated } \\
\text { using run-based cut-off } \\
\text { values as per } \\
\text { manufacturer's } \\
\text { recommendations }\end{array}$ & $\begin{array}{l}\text { 90.8\% sens. \& } \\
55.1 \% \text { spec. } \\
\text { (Desakorn et al. } \\
\text { 2012) }\end{array}$ \\
\hline
\end{tabular}




\begin{tabular}{|c|c|c|c|c|}
\hline \multirow[t]{2}{*}{$\begin{array}{l}\text { Spotted fever } \\
\text { group Rickettsiae } \\
\text { spp. }\end{array}$} & $\begin{array}{l}\text { IgG IFA:**** Rickettsia } \\
\text { conorii kits (Vircell } \\
\text { S.L., Spain) }\end{array}$ & $\begin{array}{l}\text { All AFI participants } \\
\text { and all dip-tank } \\
\text { participants }\end{array}$ & $\begin{array}{l}\text { IgG: titer of 1:40 deemed } \\
\text { positive }\end{array}$ & $\begin{array}{l}85 \% \text { sens. \& } \\
100 \% \text { spec. } \\
\text { (Do et al., } \\
2009 \text { ) }\end{array}$ \\
\hline & $\begin{array}{l}\text { IgM IFA: } \\
\text { Rickettsia conorii kits } \\
\text { (Vircell S.L., Spain) }\end{array}$ & All AFI participants & $\begin{array}{l}\text { IgM: titer of 1:192 or } \\
\text { greater deemed positive, } \\
\text { or fourfold rise in titer } \\
\text { as per manufacturer's } \\
\text { recommendations }\end{array}$ & $\begin{array}{l}\text { 94\% sens. \& } \\
\text { 95\% spec. } \\
\text { (Do et al., } \\
\text { 2009) }\end{array}$ \\
\hline \multirow[t]{2}{*}{ Q fever } & $\begin{array}{l}\text { IgG ELISA: Panbio }{ }^{\circledR} \\
\text { Coxiella burnetii (Q } \\
\text { fever) (Standard } \\
\text { Diagnostics Inc., } \\
\text { Republic of Korea) }\end{array}$ & $\begin{array}{l}\text { Convalescent } \\
\text { serum samples, or } \\
\text { acute samples } \\
\text { where convalescent } \\
\text { samples not } \\
\text { available }\end{array}$ & $\begin{array}{l}\text { Index values calculated } \\
\text { using run-based cut-off } \\
\text { values as per } \\
\text { manufacturer's } \\
\text { recommendations }\end{array}$ & $\begin{array}{l}\text { 71\% sens. \& } \\
\text { 96\% spec. } \\
\text { (Field et al. } \\
\text { 2002) }\end{array}$ \\
\hline & $\begin{array}{l}\text { IgM ELISA: Panbio }{ }^{\circledR} \\
\text { Coxiella burnetii (Q } \\
\text { fever) (Standard } \\
\text { Diagnostics Inc., } \\
\text { Republic of Korea) }\end{array}$ & $\begin{array}{l}\text { Acute serum } \\
\text { samples if } \\
\text { convalescent } \\
\text { sample not } \\
\text { available or if } \\
\text { tested positive with } \\
\text { IgG ELISA }\end{array}$ & $\begin{array}{l}\text { Index values calculated } \\
\text { using run-based cut-off } \\
\text { values as per } \\
\text { manufacturer's } \\
\text { recommendations }\end{array}$ & $\begin{array}{l}\text { 99\% sens. \& } \\
88 \% \text { spec. } \\
\text { (Field et al. } \\
\text { 2000)1 }\end{array}$ \\
\hline
\end{tabular}

* PCR: polymerase chain reaction; ${ }^{* *}$ HAI: haemagglutination inhibition assay; ${ }^{* * *}$ ELISA: enzyme-linked immunosorbent assay; ****IFA: indirect immunofluorescence assay

The DNA for the bartonella test was extracted according to Trataris et al. 2012, from packed red blood cells (obtained after spinning down EDTA tube) using the UltraClean ${ }^{\circledR}$ BloodSpin ${ }^{\circledR}$ DNA 
Isolation Kit (MoBio Laboratories, Czech Republic). The tests for leptospirosis, Q fever, brucellosis and HAI tests were not done in duplicate. The convalescent samples of the acute febrile illness patients were tested and, if found positive, then the corresponding acute samples were tested to detect seroconversion. Positive HAI samples were then tested with IgM ELISA.

\section{Statistical analysis}

Data were analysed in multivariable logistic regression models, separately for the clinic and diptank data. Test results of each test were used as binary responses variables (in different models). Backward selection of explanatory variables was applied using $\mathrm{p}=0.05$ as a cut-off. The tested explanatory variables were age (continuous), dip-tank attendance, eating wild animals, history of tick bites, herding of livestock, slaughtering of animals and eating livestock (binary) for both the clinic and dip-tank data. Confidence intervals (CI) of proportions $>0$ and $<1$ were calculated using logistic predictors whereas the exact method (assuming a binomial distribution) was used for proportions $=0$ or 1.

Ethical clearance

Ethical approval was obtained from the University of the Witwatersrand Human Ethics Committee (certificate number M120667) and signed informed consent obtained from study participants. Further permissions were secured from the Mpumalanga Provincial Government for the study to be done at the three clinics. 


\section{Results}

\section{Participant demographics and symptoms}

In the febrilers, of 119 eligible participants, 74 (62\%) were enrolled (45 were excluded as they declined consent or the study nurse could not access them). There were twenty-three (16/23 were adult) AFI patients malaria test positive during the study period, who were not included in the study. The median age of the 74 febrilers was 34 years (interquartile range [IQR] 25-47 years), 46/74 (62\%) were females, of which two were pregnant. About half were febrile on examination $(38 / 74,51 \%)$. The median duration of illness was 3 days (IQR 2-7 days). About $10 \%(6 / 74)$ were referred to hospital, and $62 \%(46 / 74)$ received an antibiotic. A quarter did not return for follow-up blood sampling $(20 / 74 ; 27 \%)$. Only 4 febrilers had with no systemic symptoms other than fever, 36/74 (49\%) presented with one other symptom, 20/74 (27\%) with two and $4 / 74(5 \%)$ with three other symptoms. The majority presented with muscle pain (85\%), while fewer had respiratory symptoms (14\%). A total of 64 dip-tanksters were recruited, of whom, 46 (72\%) were male and a median 55 years old (IQR 42-68 years). The median duration of dip-tank attendance was 15 years (IQR 6-30 years). 
Table 3. Results of laboratory tests for selected zoonotic pathogens in AFI and diptank participants with 95\% confidence interval

\begin{tabular}{|c|c|c|c|c|c|c|}
\hline & \multicolumn{3}{|c|}{ Febrilers } & \multicolumn{3}{|c|}{ Dip-tanksters } \\
\hline & Positive & $\begin{array}{l}\text { Sample } \\
\text { size }\end{array}$ & $\begin{array}{l}\% \text { positive }(95 \% \\
\mathrm{CI})\end{array}$ & Positive & $\begin{array}{l}\text { Sample } \\
\text { size }\end{array}$ & $\%$ positive $(95 \% \mathrm{CI})$ \\
\hline SFG IgG & 45 & 71 & $63.4(51.6-73.7)$ & 59 & 64 & $92.2(82.6-96.7)$ \\
\hline SFG IgM* & 13 & 53 & $24.5(14.8-37.8)$ & - & - & - \\
\hline Q fever IgG & 28 & 73 & $38.3(28.0-49.9)$ & 39 & 64 & $60.9(48.6-72.1)$ \\
\hline Q fever IgM** & 1 & 43 & $2.3(0.3-14.8)$ & 0 & 39 & $0(0-7.4)$ \\
\hline Bartonella spp. PCR & 7 & 74 & $9.5(4.6-18.5)$ & 0 & 64 & $0(0-4.6)$ \\
\hline Leptospira IgM & 5 & 74 & $6.8(2.8-15.2)$ & 14 & 64 & 21.9 (13.4-33.6) \\
\hline Brucella Ig & 1 & 74 & $1.4(0.2-9.0)$ & 0 & 64 & $0(0-4.6)$ \\
\hline Chikungunya Ig & 0 & 73 & $0(0-4.0)$ & 3 & 64 & $4.7(1.5-13.6)$ \\
\hline West Nile virus Ig & 3 & 73 & $4.1(1.3-12.0)$ & 2 & 64 & $3.1(0.8-11.7)$ \\
\hline Sindbis Ig & 1 & 73 & $1.4(0.2-9.1)$ & 2 & 64 & $3.1(0.8-11.7)$ \\
\hline Rift Valley fever Ig & 0 & 73 & $0(0-4.0)$ & 0 & 64 & $0(0-4.6)$ \\
\hline
\end{tabular}

*SFG rickettsiosis IgM (recent) done on the 45 AFI participants who were positive on SFG rickettsiosis IgG (past) and 19 IgG negative and one IgG untested participants, ${ }^{* *}$ IgM for $Q$ fever done on acute specimens for which there was no convalescent specimen and in participants that were positive for IgG.

\section{Clinical and laboratory findings}

In summary, 77\% (57/74) of febrilers tested positive for at least one of the zoonotic pathogens included in the panel (Table 3). The most prevalent past infection was the spotted fever group (SFG) (Rickettsia spp.), with 63.4\% (45/71, 95\% CI 51.6-73.7\%) testing positive for anti-

Rickettsia IgG, while anti-Rickettsia IgM was positive in 24.5\% (13/53, 95\% CI 14.8-37.8\%) of 
febrilers, indicating a more recent or current infection. Of the 13 anti-Rickettsia IgM positive patients, twelve were anti-Rickettsia IgG positive. Antibodies (IgG) to Coxiella burnetii, the causative agent of Q fever, were detected in 38.3\% (28/73, 95\% CI 28.0-49.9\%) of patients. Other bacterial pathogens included bartonellosis with 9.5\% PCR-positive (7/74, 95\% CI 4.618.5\%), that were identified as Bartonella vinsonii subspecies berkoffii $(\mathrm{n}=1)$ (which has a dog reservoir), B. henselae $(\mathrm{n}=2)$ (domestic cat reservoir), B. quintana $(\mathrm{n}=1)$ (human reservoir (Zeaiter et al. 2002)), B. thailandensis ( $\mathrm{n}=1$ ) (rodent reservoir (Saisongkorh et al. 2009)) and two Bartonella positives are unnamed, but rodent borne. Leptospirosis with 6.8\% (5/74, 95\% CI 2.8-15.2\%) group-specific IgM antibodies and brucellosis with 1.4\% (1/74, 95\% CI 0.2-9.0\%) group-specific total antibodies were also found. West Nile and Sindbis fever antibodies were detected in $4.1 \%(3 / 73,95 \% \mathrm{CI} 1.2-12.0 \%)$ and $1.4 \%$ (1/73, 95\% CI 0.2-9.1\%) of febrilers respectively. No chikungunya or Rift Valley fever (RVF) antibodies were found.

In the dip-tanksters, the proportion with anti-Rickettsia IgG antibodies was also high at $92.2 \%$ (59/64, 95\% CI 82.6-96.7\%), and 60.9\% (39/64, 95\% CI 48.6-72.1\%) had anti-Coxiella IgG antibodies. No evidence for exposure to Brucella spp. was detected, but 21.9\% (14/64, 95\% CI 13.4-33.6\%) tested positive for Leptospira IgM antibodies. For viral aetiologies, 3.1\% (2/64, 95\% CI 0.8-11.7\%) of dip-tanksters tested positive for West Nile virus IgM, 4.7\% (3/64, 95\% CI 1.5-13.6\%) for chikungunya and 3.1\% $(2 / 64,95 \%$ CI $0.8-11.7 \%)$ for Sindbis virus antibodies. No RVF antibodies were detected. 
The AFI participant arbovirus HAI positive samples were retested with IgM ELISA and had the following results: the three WNV positive samples had two negative results and one untested and the Sindbis positive was also IgM positive. Amongst dip-tank participants: for chikungunya one of the three HAI-positive samples was also IgM positive, one was negative and the last untested; both WNV HAI-positive samples were IgM negative, and both Sindbis HAI-positive samples were also IgM positive.

The only risk factor that was statistically significantly associated with a disease was attending dip-tanks in febrilers for $\mathrm{Q}$ fever IgG ( $\mathrm{p}=0.007)$. Thirteen of the $74(18 \%)$ febrilers were found to have previously attended dip-tanks and of those tested $77 \%$ (10/13) were IgG positive compared to $31 \%(19 / 62)$. None of the risk factors for the dip-tanksters were associated with the test results.

\section{Discussion}

Our study looked at both acutely febrile participants in clinics and cattle dip-tank participants at high risk for zoonoses. Undifferentiated acute febrile illness is among the most common presenting signs in patients seeking medical care in Africa (Perkins et al. 1997; Crump et al. 2003; Van Hemelrijck et al. 2009). Despite this, the syndrome is frequently misdiagnosed, and the aetiologies still poorly understood. Febrile illness is often misclassified as malaria, especially in adults living in areas with low to moderate malaria transmission (Reyburn 2004; Chandler et al. 2008; Nankabirwa et al. 2009). Misdiagnosis leads to delays in appropriate treatment and higher case-fatality rates (Chandler et al. 2008). 
This study showed that $77 \%$ of febrilers and $98 \%$ of dip-tanksters had at least one positive test. Bartonellosis (PCR 9.5\%), spotted fever (IgM 24.1\%), and less likely, leptospirosis (IgM 6.8\%) and Q fever (IgM 2.3\%) could have been the cause of the acute febrile illness in the febrilers, as IgM and PCR suggest recent or current infection. This is a valuable finding, relevant to the management of clinic patients, as amoxicillin is the standard treatment for patients with AFI, but it would not be effective for these diseases. Therefore, the AFI treatment algorithms in this and similar settings need to be reconsidered and health staff educated on these infections.

The febrilers also showed a high past exposure (IgG) to SFG Rickettsia spp. (63.4\%) and Q fever (37.8\%), not previously described in this population. The high proportion of exposure to Rickettsia spp. is understandable, given that $70 \%$ of tick pools and $100 \%$ of flea pools taken from dogs in the area were positive for Rickettsia spp. (Kolo et al. 2016). Over 70\% (50/71) of febrilers had either an SFG Rickettsia spp. or Q fever positive result, while 95\% of dip-tanksters had either an SFG Rickettsia spp. or Q fever positive result. We expect veterinary staff or livestock herders and farmers presenting at the dip-tanks with their livestock to be at a higher risk for zoonotic diseases (especially for those diseases transmitted by vectors/reservoirs and associated with livestock) in this population. However, the only diseases where dip-tanksters had a confidence interval higher than febrilers was spotted fever (IgG). There are differences between proportions of participants positive in the febrilers and dip-tanksters but this is not strongly statistically supported in this study. 
Dip-tanksters are on average 21 years older than febrilers and therefore have had more time for exposure to pathogens. Although, the number of zoonotic illnesses per individual was not correlated with years of dip-tank attendance in the dip-tank group, contact with cattle dip-tanks was positively associated with Q fever exposure in AFI patients. The higher proportion of spotted fever IgG in dip-tank participants could be from cattle owners having higher levels of exposure to ticks, related to their dogs and other domestic animals that they will interact with daily. There was little evidence of other risk factors contributing to positive serology. The lack of positive associations may be due to a relatively small sample size and test-positives. Also, the environment is homogenous such that even if people say they do not own or work with animals, some contact is inevitable, due to the free-ranging nature of the animals and their close proximity to humans; for example, almost a fifth of the febrilers had some contact with the diptanks.

The higher bartonellosis test-positive proportion in febrilers could be as the test was detecting organisms and not antibodies, which would be more closely associated with patients [presenting with fever than compared to dip-tanksters. Bartonella infection rate in other studies was also found to be high in HIV-infected individuals (Frean et al. 2002; Trataris et al. 2012), and although our participants were not tested for HIV, HIV prevalence may have been higher in the febrilers that had an average age of 34 years compared to the dip-tankster with an average age of 55 years, which correlates with the provincial age and HIV prevalence demographics (Shisana et al. 2014). The Bartonella species found in the febrilers were associated with humans $(\mathrm{n}=1)$ and domestic dogs and cats $(\mathrm{n}=3)$ and rodents $(\mathrm{n}=2)$. Bartonella 
infections have been found to be common in cats (23.5\%) and dogs (9\%) in a southern African study (Trataris et al. 2012), and in fleas (36.3\%) elsewhere in Africa (Leulmi et al. 2014).

A review of leptospirosis in sub-Saharan Africa, noted very few human studies, with most data being from animals studies (De Vries et al. 2014). In our study evidence of leptospirosis was higher in the dip-tanksters, although with confidence intervals overlapping, which again makes sense given that transmission to humans is from the urine of infected animals, commonly rodents, pigs and other domestic animals. Cattle in a neighbouring province had a leptospirosis prevalence of almost 20\% (Hesterberg et al. 2009) and a South African study found leptospirosis in 4.7\% (25/530) of dogs tested (Roach et al. 2010). What is more difficult to understand is the dip-tanksters having a threefold higher IgM (which should indicate current or recent infection), than AFI patients. The dip-tank participants may be more consistently exposed to Leptospira spp., but not present with fever at the clinic. The Leptospira ELISA IgM is known to have a low specificity (55\%) and diagnostic accuracy, which may influence the reliability of the results (Desakorn et al. 2012).

The brucellosis results are reflective of what has been found in domestic animals in the area. Although brucellosis is present in the region (Hesterberg et al. 2008), unpublished studies suggest that there is no brucellosis in the cattle, goats and dogs in the study area (Dr G Simpson, Pers. comm.,15 ${ }^{\text {th }}$ June 2017). This indicates that the control mechanisms of heifer vaccination and movement control may be keeping the disease at bay, even though there are high 
seroprevalences in buffalo (8.7-47.6\%) across the neighbouring reserve fences (Gorsich et al. 2015).

The febrilers had 5.5\% (4/73) showing at least one positive arbovirus positive result compared to the dip-tanksters with $10.9 \%(7 / 64)$. Little is known about the epidemiology of chikungunya virus in the region, although baboons (Papio ursinus) were previously found to be the primary vertebrate reservoir (Mcintosh et al. 1977). The vectors are tree canopy-associated Aedes fucifer-taylori group, which are less likely to be found in a peri-domestic situation, and which rarely feed on humans. The dip-tank participants may be more at risk as they take their cattle and goats into the surrounding bushveld for grazing. The presence of West Nile and Sindbis virus infections, although at low levels, is of interest as patients are not routinely tested for these diseases. There are also veterinary implications associated with their presence.

Vectors can move pathogens between wildlife and domestic animals species (Bengis et al. 2004). This phenomenon is of growing concern with the expanding human populations, habitat destruction, intensification of wildlife and potentially greater contact between humans and wildlife (Bengis et al. 2004). The diseases investigated in this study can be transmitted to humans through vectors, food, contact or contamination of the environment, which has implications for vector, hygiene and environmental control. Malaria control in the area, for example, has had a negative impact on some mosquito populations, which may affect other mosquito-transmitted diseases. Further vector control, disease control in animals, as well as food and other hygiene improvements, would be beneficial in decreasing the burden of these 
diseases. There is also a need to educate the population about reducing tick and surface water contact.

A limitation of our study was that sample sizes were small. There was only one nurse covering three clinics for AFI patients, which made it difficult to access all the eligible patients. The diptank participants were opportunistically selected in a non-random manner. This could influence the extrapolation of the results to all the dip-tank attendees.

\section{Conclusions}

Bartonella spp., Rickettsia spp., Coxiella burnetii and Leptospira spp. are present and could be undetected causes of fever and illness in a community bordering wildlife reserves in the northeast of South Africa. Some acute febrile illness patients (9.5\%) were infected with Bartonella spp. associated with human, rodent and domestic dog and cat reservoirs. A high proportion of cattle dip-tank attendees and acute febrile illness patients had evidence of past infection or background exposure to Rickettsia spp. and Coxiella burnetii, which is of relevance to public and veterinary health. Current acute febrile illness treatment algorithms at the clinics prescribe amoxicillin, which would not be effective for these diseases. The low proportion of brucellosis and viral infections is encouraging, but should continue to be monitored. The vector control strategies for livestock and public health should take into account ticks and fleas as they transmit Bartonella spp. and Rickettsia spp. Animal husbandry should be adapted to include means of infection prevention, such as disinfection, after contact with animal excretions to 
decrease $\mathrm{Q}$ fever, leptospirosis and potentially brucellosis. This is an opportunity for public and animal health organisations to discuss control programs to tackle common afflictions. Wider zoonotic surveillance should be continued, and veterinary and public health services should be aware of these diseases, their diagnoses and treatments, and educate their patients and owners in prevention methods and care seeking.

\section{Acknowledgements}

This study was funded by Swedish Civil Contingencies Agency (MSB) and Swedish International Development Cooperation Agency (SIDA) and by the Global Disease Detection Program. We thank Sr. Aletta Ennica Ntlemo for her hard work collecting the information and samples from patients and following them up, Mpumalanga Veterinary Services, Hans Hoheisen Wildlife Research Station, Hluvukani Animal Clinic and staff, the staff and patients of Gottenburg, Utha and Welverdiend Clinics, cattle farmers, herders and veterinary staff of Gottenburg, Utha, Welverdiend A and B and Thlavekisa diptanks who volunteered for the study.

All the authors declare no competing financial interests in the execution or communication of this study and its findings.

\section{References}

Bengis RG, Leighton FA, Fischer JR, Artois M, et al. The role of wildlife in emerging and re- 
emerging zoonoses. Rev Sci Tech Off Int Epiz 2004 23:497-511.

Berrian AM, van Rooyen J, Martínez-López B, Knobel D, et al. One Health profile of a community at the wildlife-domestic animal interface, Mpumalanga, South Africa. Prev Vet Med 2016 130:119-128.

Biggs HM, Bui DM, Galloway RL, Stoddard RA, et al. Leptospirosis among hospitalized febrile patients in northern Tanzania. Am J Trop Med Hyg 2011 85:275-281.

Casao MA, Navarro E, Solera J. Evaluation of Brucellacapt for the diagnosis of human brucellosis. J Infect 2004 49:102-108.

Chandler CIR, Chonya S, Boniface G, Juma K, et al. The importance of context in malaria diagnosis and treatment decisions - a quantitative analysis of observed clinical encounters in Tanzania. Trop Med Int Heal 2008 13:1131-1142.

Crump JA, Youssef FG, Luby SP, Wasfy MO, et al. Estimating the incidence of typhoid fever and other febrile illnesses in developing countries. Emerg Infect Dis 2003 9:539-544.

Desakorn V, Wuthiekanun V, Thanachartwet V, Sahassananda D, et al. Accuracy of a commercial IgM ELISA for the diagnosis of human leptospirosis in Thailand. Am J Trop Med Hyg 2012 $86: 524-527$.

Do EJ, Kim JE, Park JM, Lee KM, et al. Development of recombinant OmpA and OmpB proteins as diagnostic antigens for rickettsial disease. Microbiol Immunol 2009 53:368-374.

Field PR, Mitchell JL, Santiago A, David J, et al. Comparison of a commercial enzyme-linked immunosorbent assay with immunofluorescence and complement fixation tests for detection of 
C. burnetii (Q fever) immunoglobulin M. J Clin Microbiol 2000 38:1645-1647.

Field PR, Santiago A, Chan S-W, Patel DB, et al. Evaluation of a novel commercial Enzyme-Linked Immunosorbent Assay detecting Coxiella burnetii -Specific Immunoglobulin G for $\mathrm{Q}$ fever prevaccination screening and diagnosis. J Clin Microbiol 2002 40:3526-3529.

Frean J, Anrdt S, Spencer D. High rate of Bartonella henselae infection in HIV-positive outpatients in Johannesburg, South Africa. Trans R Soc Trop Med Hyg 2002 96:549-550.

Froberg MK, Dannen D, Bakken JS. Babesiosis and HIV. Lancet 2004 363:704.

Gorsich EE, Ezenwa VO, Cross PC, Bengis RG, et al. Context-dependent survival, fecundity and predicted population-level consequences of brucellosis in African buffalo. J Anim Ecol 2015 84:999-1009.

Grace D, Mutua F, Ochungo P, Kruska R, et al. Mapping of Poverty and Likely Zoonoses Hotspots. Zoonoses Project 4.; Nairobi, 2012a.

Grace D, Gilbert J, Randolph T, Kang'ethe E. The multiple burdens of zoonotic disease and an ecohealth approach to their assessment. Trop Anim Health Prod 2012b 44:67-73.

Grace D, Lindahl J, Wanyoike F, Bett B, et al. Poor livestock keepers: ecosystem-poverty-health interactions. Philos Trans R Soc Lond B Biol Sci 2017372.

Van Hemelrijck MJJ, Lindblade KA, Kubaje A, Hamel MJ, et al. Trends observed during a decade of paediatric sick visits to peripheral health facilities in rural western Kenya, 1997-2006. Trop Med Int Heal 2009 14:62-69.

Hesterberg UW, Bagnall R, Perrett K, Bosch B, et al. A serological prevalence survey of Brucella 
abortus in cattle of rural communities in the province of KwaZulu-Natal, South Africa. J S Afr Vet Assoc 2008 79:15-18.

Hesterberg UW, Bagnall R, Bosch B, Perrett K, et al. A serological survey of leptospirosis in cattle of rural communities in the province of KwaZulu-Natal, South Africa. J S Afr Vet Assoc 2009 4549.

John K, Kazwala R, Mfinanga GS. Knowledge of causes, clinical features and diagnosis of common zoonoses among medical practitioners in Tanzania. BMC Infect Dis 2008 8:162.

Jones KE, Patel NG, Levy MA, Storeygard A, et al. Global trends in emerging infectious diseases. Nature 2008 451:990-995.

Kolo AO, Sibeko-Matjila KP, Maina AN, Richards AL, et al. Molecular detection of zoonotic Rickettsiae and Anaplasma spp. in domestic dogs and their ectoparasites in Bushbuckridge, South Africa. Vector-Borne Zoonotic Dis 2016 16:245-252.

Laudisoit A, Iverson J, Neerinckx S, Shako J-C, et al. Human seroreactivity against Bartonella species in the Democratic Republic of Congo. Asian Pac J Trop Med 2011 4:320-322.

Lennette EH, Schmidt NJ. Diagnostic Procedures for Viral, Rickettsial and Chlamydial Infections, 5th ed.; Lennette, E. H., Schmidt, N. J., Eds.; American Public Health Assn: Washington, 1979.

Leulmi H, Socolovschi C, Laudisoit A, Houemenou G, et al. Detection of Rickettsia felis, Rickettsia typhi, Bartonella species and Yersinia pestis in fleas (Siphonaptera) from Africa. PLoS Negl Trop Dis 2014 8:e3152.

Maharaj R, Raman J, Morris N, Moonasar D, et al. Epidemiology of malaria in South Africa : From 
control to elimination. South African Med J 2013 103:779-783.

Maina AN, Knobel DL, Jiang J, Halliday J, et al. Rickettsia felis infection in febrile patients, western Kenya, 2007-2010. Emerg Infect Dis 2012 18:328-331.

Mcintosh BM, Jupp PG, Santos ID. Rural Epidemic of Chikungunya in South-Africa with Involvement of Aedes-(Diceromyia)-Furcifer-(Edwards) and Baboons. S Afr J Sci 1977 73:267269.

Nankabirwa J, Zurovac D, Njogu JN, Rwakimari JB, et al. Malaria misdiagnosis in Uganda-implications for policy change. Malar J 2009 8:66.

Njeru J, Melzer F, Wareth G, El-Adawy H, et al. Human Brucellosis in Febrile Patients Seeking Treatment at Remote Hospitals, Northeastern Kenya, 2014-2015. Emerg Infect Dis 2016 $22: 2160-2164$.

Paweska JT, Burt FJ, Swanepoel R. Validation of IgG-sandwich and IgM-capture ELISA for the detection of antibody to Rift Valley fever virus in humans. J Virol Methods 2005 124:173-181.

Perkins BA, Zucker JR, Otieno J, Jafari HS, et al. Evaluation of an algorithm for integrated management of childhood illness in an area of Kenya with high malaria transmission. Bull World Health Organ 199775 Suppl 1:33-42.

Prabhu M, Nicholson WL, Roche AJ, Kersh GJ, et al. Q fever, spotted fever group, and typhus group rickettsioses among hospitalized febrile patients in northern Tanzania. Clin Infect Dis 2011 53:e8-15.

Reyburn H. Overdiagnosis of malaria in patients with severe febrile illness in Tanzania: a 
prospective study. BMJ 2004 329:1212-0.

Roach JM, van Vuuren M, Picard J a. A serological survey of antibodies to Leptospira species in dogs in South Africa. J S Afr Vet Assoc 2010 81:156-159.

Rodríguez-Prieto V, Vicente-Rubiano M, Sánchez-Matamoros a., Rubio-Guerri C, et al. Systematic review of surveillance systems and methods for early detection of exotic, new and re-emerging diseases in animal populations. Epidemiol Infect 2015 143:2018-2042.

Saisongkorh W, Wootta W, Sawanpanyalert P, Raoult D, et al. “Candidatus Bartonella thailandensis": A new genotype of Bartonella identified from rodents. Vet Microbiol 2009 139:197-201.

Shisana O, Rehle T, Simbayi LC, Zuma K, et al. South African National HIV Prevalence, Incidence and Behaviour Survey, 2012. HSRC Press 2014194.

Statistics South Africa (SSA). Census 2011 Municipal Report: Mpumalanga; Pretoria, South Africa, 2012.

Thrusfield M V. Veterinary Epidemiology, 2nd ed.; Thrusfield, M. V, Ed.; Blackwell Science Ltd: London, UK, 1995.

Trataris AN, Rossouw J, Arntzen L, Karstaedt A, et al. Bartonella spp. in human and animal populations in Gauteng, South Africa, from 2007 to 2009. Onderstepoort J Vet Res 2012 79:1-8.

De Vos V, Van Niekerk CAW. Brucellosis in the Kruger National Park. J S Afr Vet Assoc 1969 40:331-334.

De Vries SG, Visser BJ, Nagel IM, Goris MGA, et al. Leptospirosis in sub-Saharan Africa: a 
systematic review. Int J Infect Dis 2014 28:e47-e64.

Zeaiter Z, Liang Z, Raoult D. Genetic classification and differentiation of Bartonella species based on comparison of partial ftsZ gene sequences. J Clin Microbiol 2002 40:3641-3647.

Zumla A, Dar O, Kock R, Muturi M, et al. Taking forward a "ONE HEALTH" approach for turning the tide against The Middle East Respiratory Syndrome Coronavirus and other zoonotic pathogens with epidemic potential. Int J Infect Dis 2016 47:5-9. 